\title{
Municipal Solid Waste Compost Suppresses Weeds in Vegetable Crop Alleys
}

\author{
Nancy E. Roe ${ }^{1}$ and Peter J. Stoffella ${ }^{2}$ \\ University of Florida, Institute of Food and Agricultural Sciences, Agricultural \\ Research and Education Center, P. O. Box 248, Ft. Pierce, FL 34954 \\ Herbert H. Bryan' \\ University of Florida, Institute of Food and Agricultural Sciences, Tropical \\ Research and Education Center, 18905 SW 280th Street, Homestead, \\ FL 33031
}

Additional index words. mulch, herbicide, glyphosate, polyethylene

Abstract. A mulch of municipal solid waste compost at $224 \mathrm{t} \cdot \mathrm{ha}^{-1}$ was compared with glyphosate sprays and a nontreated check for weed control in vegetable crop bed alleys during Spring and Summer 1992. In both experiments, there was a significantly lower percentage of weed coverage in the compost mulch and herbicide spray plots than in the control plots. Weed control in the compost and herbicide treatments was similar. In the spring experiment, tractor tire traffic through the alleys reduced weed growth in all plots by $62 \%$ and $44 \%$ at 16 and 73 days after treatment initiation, respectively. These results suggest that municipal solid waste compost may have potential as a viable mulch for weed control in vegetable crop alleys. Chemical name used: isopropylamine salt of $N$-(phosphonomethyl) glycine (glyphosate).

The large percentage of paper materials in most municipal waste streams results in compostthat may form a crust after wetting, thereby providing some degree of weed control. The purpose of this investigation was to evaluate weed coverage and growth in alleys mulched with municipal waste compost or treated with glyphosate herbicide.

The experiments were conducted on a commercial bell pepper (Capsicum annuum L.) farm at Delray Beach, Fla. The soil was a Myakka sand (sandy, siliceous, hyperthermic Aeric Haplaquod). About 30 days before the start of the experiment, raised beds $20 \mathrm{~cm}$ high and $92 \mathrm{~cm}$ wide were fumigated with a $98 \%$ methyl bromide : $2 \%$ chloropicrin mixture at $202 \mathrm{~kg} \cdot \mathrm{ha}^{-1}$ and covered with full-bed white polyethylene mulch. -Beds were spaced $1.68 \mathrm{~m}$ apart, center to center, with $76-\mathrm{cm}$-wide alleys between the beds. Plots (6. $1 \mathrm{~m}$ in length) consisted of an alley between two beds. Compost was applied manually to bed alleys on 14 Feb. 1992. We used 1) municipal solid waste compost (Reuter Recycling of Florida, Pembroke Pines) applied at $224 \mathrm{t} \cdot \mathrm{ha}^{-1}(\approx 5 \mathrm{~cm}$ thick); 2) glyphosate spray applied with a backpack sprayer (3 liters.ha ${ }^{-1}$ ) on 28 Feb., 16 Mar., and 4 Apr.; and 3) a nontreated control. The compost had a pH of 7.9 and contained 7.5

Received for publication 8 Feb. 1993. Accepted for publication 28 June 1993. University of FloridaAgr. Expt. Sta. Journal series no. R-02951. The cost of publishing this paper was defrayed in part by the payment of page charges. Under postal regulations, this paper therefore must be hereby marked advertisement solely to indicate this fact.

'Postdoctoral Research Associate. 2professor.
dS total soluble salts $/ \mathrm{m}$, and $5100 \mathrm{~N}-433 \mathrm{P}-$ $1593 \mathrm{~K}$ (inmilligramsperkilogramdry weight). Tractors passed through half of the alleys on 21 Feb.; 4, 14, and 24 Mar.; and 1 Apr. These alleys were designated "traffic" alleys. There was no traffic in the other alleys. Weed cover (percent ground coverage) was subjectively evaluated on 3 Mar. and 28 Apr. Principal species found in the plots were the broadleaf weeds Richardia scabra L. and Chamaesyce spp. (L.) Millspaugh and the grass Eleusine indica Gaertn. On 12 May, grassy and broadleaf weeds (percent ground coverage) in each no-traffic plot were subjectively evaluated. Weeds were then severed at the soil surface from two $30 \times 30-\mathrm{cm}$ areas in each plot, dried at $70 \mathrm{C}$ for 8 days, and dry weights were recorded. A split-block design with traffic treatment as the main block and weed control method as split block was used. Each treatment was replicated five times.

The experiment was repeated in a different field area on 22 May 1992. In this experiment, no polyethylene mulch was used on the beds, there was no tire traffic, and the glyphosate spray on the herbicide plots was applied only on 1 July. Weed coverage percentages were recorded on 28 July and 21 Aug. 1992. The design was a randomized complete block with treatments replicated five times.

Data collected from each experiment were subjected to analysis of variance and treatment means separation by Duncan's multiple range test at $P \leq 0.05$.

No significant interactions between traffic and weed control method occurred for any measured variable in the firstexperiment therefore, only main effects are presented (Table 1). A significantly higher percentage of ground was covered with weeds in control plots than in either the compost or herbicide plots, but 16 days after application, percent ground coverage of weeds was similar for the compost and herbicide spray plots (Table 1). Compost plots had a lower percent weed ground coverage than the control or herbicide plots 73 days after application. The increase in weed percent ground coverage in the herbicide plots suggests that substantial weed regrowth occurred during the 24 days between the last herbicide spray and the second rating date. Tire traffic significantly lowered percent weed ground coverage at each observation date (Table 1).

Dry weight of weeds was significantly higher in control and compost plots than in the herbicide plots, despite the lower percentage of weed ground coverage in compost plots (Table 1). The relatively higher weed weight in compost plots was the result of a higher percent ground coverage by larger broadleaf weeds in the compost plots compared with the herbicide and control plots. The compost contains $<1 \%$ (dry-weight basis) each of $\mathrm{N}, \mathrm{P}$, and $\mathrm{K}$, but when it is used at these high rates, the added nutrition may have encouraged weed, particularly broadleaf weed, growth.

In the summer experiment, weed coverage was significantly higher $(P \leq 0.05)$ in the control plots ( $31 \%$ at 67 days, $36 \%$ at 91 days) than in either the compost or herbicide plots, for which the results were similar, with a range Of $2 \%$ to $13 \%$.

Organic mulches have been reported to control weeds better than herbicides (AparbalSingh et al., 1985; Ingle and Bussell, 1988; Kolb et al., 1985). Kolb (1983) obtained the highest weed control in low-growing ornamental shrubs with a combination of herbicide and bark or sawdust mulches. However, herbicides also have improved weed control when compared to organic mulches (Clemens and Starr, 1985).

A mulch of municipal solid waste compost

Table 1. Percent ground coverage by all weeds and broadleaf weeds, and total weed weights from bed alleys treated with herbicide, mulched with municipal waste compost, or nontreated, and with or without tire traffic through alley (spring experiment).

\begin{tabular}{|c|c|c|c|c|}
\hline \multirow[b]{4}{*}{ Treatment } & \multicolumn{3}{|c|}{ Ground coverage (\%) } & \multirow[b]{2}{*}{ Weeds } \\
\hline & \multicolumn{2}{|c|}{$\begin{array}{c}\text { Days after } \\
\text { application }\end{array}$} & \multirow{3}{*}{$\begin{array}{c}\text { Broadlea } \\
\text { weeds }^{\mathrm{z}}\end{array}$} & \\
\hline & 16 & 73 & & dry $w t^{2}$ \\
\hline & \multicolumn{2}{|c|}{ All weeds } & & (g) \\
\hline \multicolumn{5}{|l|}{$\begin{array}{l}\text { Weed control } \\
\text { method } \\
\text { (WCM) }\end{array}$} \\
\hline Control & $56 a^{y}$ & $72 a$ & $24 \mathrm{~b}$ & $28.4 \mathrm{a}$ \\
\hline Herbicide & $27 b$ & $49 \mathbf{a}$ & $24 \mathrm{~b}$ & $9.1 \mathrm{~b}$ \\
\hline Compost & $17 \mathrm{~b}$ & $21 b$ & $85 a$ & $28.3 \mathrm{a}$ \\
\hline \multicolumn{5}{|l|}{ Traffic (T) } \\
\hline+ & 18 & 34 & & \\
\hline- & 49 & 61 & & \\
\hline F test & $* *$ & $* *$ & & \\
\hline $\mathrm{WCM} \times \mathrm{T}$ & NS & NS & & \\
\hline
\end{tabular}

${ }^{2}$ Data obtained from nontraffic plots, 85 days after application.

'Treatment means within columns separated by Duncan's multiple range test, $P \leq 0.05$. ss.** Nonsigniticant or significant at $P \leq 0.01$. 
was as effective in controlling weeds in alleys as one to three glyphosate applications. Analyzing the material's effectiveness over longer use, and its effect on crops and soils, are necessary before recommendations can be made.

\section{Literature Cited}

Aparbal-Singh, Man-Singh, D.V. Singh, A. Singh, and M. Singh. 1985. Relative efficacy of organic mulch and herbicides for weed control in Cymbopogon species. Ann. Conf. Indian Soc. Weed Sci. p. 77. (Abstr.)

Clemens, J. and R.K. Starr. 1985. Field establishment of container grown plants. J. Environ. Mgmt. 21:257-261.

Ingle, A. and W.T. Bussell. 1988. Mulches for weed control in asparagus and kiwifruit. Proc. New
Zealand Weed Pest Control Conf. p. 57-60.

Kolb, W. 1983. Effect of soil disinfection and of mulching on the maintenance of planted areas. Gartenamt 32:374-376.

Kolb, W., T. Schwarz, and R. Trunk. 1985. Effect of mulching on rooting, cost of maintenance, and growth of low perennials and shrubs. RasenGrunflachen-Begrunungen 16:120-126. 